\title{
WHERE IS THE TRANSGENDER IN THE TRANSCANADIAN? KAI CHENG THOM AND VIVEK SHRAYA'S RESPONSE-ABLE FICTIONS*
}

\author{
Libe García Zarranz \\ Norwegian University of Science and Technology (NTNU)
}

\begin{abstract}
This article seeks to activate a much-needed discussion about the place of transgender literary production within the field of transCanadian literature, in its multifaceted iterations. The motivation behind it sparks from the imperative to respond, while simultaneously being accountable for the narratives we produce as feminist researchers in a moment of increasing racism, transphobia, and social divisiveness in Canadian literary communities. Departing from this desire, this article turns to Kai Cheng Thom and Vivek Shraya's ethico-poetic storying and worlding through the lens of queer and trans philosophers Donna Haraway, Karen Barad, and Susan Stryker. Thom's Fierce Femmes and Notorious Liars: A Dangerous Trans Girl's Confabulous Memoir (2016) and Shraya's She of the Mountains (2014), I contend, pose a critique of the multiple modes of violence targeting racialized queer and trans communities, while simultaneously situating response-ability as an ethical compass from which to navigate, and not drown, in this global era of indifference.
\end{abstract}

KeYwords: transgender, transCanadian, response-ability, Kai Cheng Thom, Vivek Shraya.

\section{¿DÓNDE ESTÁ LO TRANSGÉNERO EN LO TRANSCANADIENSE? LA RESPONS-HABILIDAD EN LAS FICCIONES DE KAI CHENG THOM Y VIVEK SHRAYA}

\section{RESUMEN}

Este artículo busca activar una necesaria conversación sobre el lugar de la producción literaria transgénero dentro del campo de la literatura transcanadiense, en sus múltiples versiones. Mi motivación surge del imperativo de responder a, y de ser responsable de, las narrativas que producimos como investigadoras feministas en un momento de creciente racismo, transfobia y división social en las comunidades literarias canadienses. Partiendo de este deseo, este artículo se aproxima a la obra ético-poética de Kai Cheng Thom y Vivek Shraya a través de la perspectiva de la filosofía queer y trans de Donna Haraway, Karen Barad, y Susan Stryker. Propongo que las ficciones de Thom y Shraya, como ilustran los libros Fierce Femmes and Notorious Liars: A Dangerous Trans Girl's Confabulous Memoir (2016) y She of the Mountains (2014), plantean una crítica a la violencia contra comunidades racializadas queer y trans, al mismo tiempo que sitúan la respons-habilidad como brújula ética con la que navegar, y no ahogarse, en esta era global de la indiferencia.

Palabras Clave: transgénero, transcanadiense, respons-habilidad, Kai Cheng Thom, Vivek Shraya.

DOI: https://doi.org/10.25145/j.recaesin.2019.78.10

Revista Canaria de Estudios Ingleses, 78; April 2019, pp. 141-153; ISSN: e-2530-8335 
there are no words in your mouth

but there's a pen in your head you want to tell the truth

but you told stories instead -Kai Cheng Thom, “in your mouth” (2017)

Ethics is [...] about responsibility and accountability for the lively relationalities of becoming of which we are a part. -Donna J. Haraway (2007)

Opening up to a new field of studies is a moment of "absolute feeling" (131), to borrow the words of Vivek Shraya's protagonist in She of the Mountains (2014): a moment of exhilaration, but also doubt; possibility, but also hesitancy; learning, but also inadequacy. Touching upon new methods demands an ethical response-ability, particularly when we seek to engage in transdisciplinary work. I here follow feminist theorist and physicist Karen Barad when she boldly claims that "Theorizing, a form of experimenting, is about being in touch. What keeps theories alive and lively is being responsible and responsive to the world's patternings and murmurings" ("On Touching" 207). Following this line of enquiry, this essay seeks to activate a much-needed discussion about the place of transgender literary production in Canada within the field of transCanadian literature, in its multifaceted iterations (see Kamboureli and Miki; Martín-Lucas; García Zarranz). The motivation behind it sparks from the imperative to be response-able, that is, to respond, while simultaneously being accountable for the narratives we produce as feminist researchers in a moment of increasing racism, transphobia, and social divisiveness in Canadian literary communities. ${ }^{1}$

In "Sowing Worlds" (2013), Haraway characterizes our current epoch as one of urgency; a messy time that demands that we "[s]tay with the trouble!" (117). In order to do so, we need to put reciprocity, accountability, and response-ability at the centre of critical enquiry when we unlearn prescribed worlds and listen to untold stories in an age of global neoliberalism. The pressing demand to stay with the trouble stands at the core of Kai Cheng Thom and Vivek Shraya's fierce storying and worlding (Haraway "Sowing"), as I claim in this article. In different but related ways, their fictions are populated by queer and trans subjects and communities whose survival largely depends on the ability to respond to violence. This unsus-

* Selections from this article were presented at the British Association for Canadian Studies (BACS) annual conference (London, UK, April 2017) and in Dr. Aida Rosende Pérez's seminar, "Cultural Politics of In/Difference," at the Universitat de les Illes Balears (Spain, Nov. 2017). This research was also funded by the projects Bodies in Transit 2: Difference and Indifference (Ref. FFI2017-84555C2-2-P, Spanish Ministry of Economy, Industry \& Competitiveness) and Sustainable Trans/national Literacies: Ethics, Emotions, Pedagogy (Faculty of Social \& Educational Sciences, NTNU, Norway).

${ }^{1}$ I am here thinking of recent debacles such as the Appropriation Prize or the UBC Accountable. See the forthcoming Refuse: CanLit in Ruins, co-edited by Hannah McGregor, Julie Rak, and Erin Wunker, for a critical analysis of these controversies. 
tainable mode of life is, in this case, ordinary, so these populations cannot afford to look away but must stay in the present and remain immersed in troubled waters. This process, I argue, demands response-able modes of ethical intervention that would destabilize terror in its multiple iterations. Thom and Shraya's counter narratives, as illustrated in Fierce Femmes and Notorious Liars: A Dangerous Trans Girl's Confabulous Memoir (2016) and the already mentioned She of the Mountains, pose a critique of the violence targeting racialized queer and trans populations. Simultaneously, they situate response-ability as an ethical compass from which to navigate, and not drown, in today's global age of indifference.

I here use the hyphen following queer philosophers Donna Haraway and Karen Barad who have unravelled the subtleties and entanglements intrinsic to the term responsibility, now spelled "response-ability". Haraway, who has written extensively about shared suffering and responsible conduct, aptly contends that we need to "open passages for a praxis of care and response -response-ability-in ongoing multispecies worlding on a wounded terra" ("Awash" 302). Response-ability here entails the capacity to respond, while simultaneously being accountable for your actions. In related ways, Barad discusses this formulation in terms of agency: "agency is about response-ability, about the possibilities of mutual response, which is not to deny, but to attend to power imbalances" (Dolphijn and van der Tuin 55). This article is a first attempt to tease out the many shapes a praxis of response-ability can take, including the ruptures, paradoxes, and tensions that emerge when responseability is represented in queer and trans texts produced by transCanadian writers.

What happens then when we put the transgender and the transCanadian in touch? Deploying a material feminist approach, Barad persuasively contends that " $[t]$ ouching is a matter of response. Each of 'us' is constituted in response-ability. Each of 'us' is constituted as responsible for the other, as the other" "On Touching" 215). Following Barad, I want to put the transgender and the transCanadian in "touch" in ways that enable response-ability. I will argue that transCanadian literature shares a "decolonization imperative" (Lai, 31) with transgender writing, particularly with racialized trans positions, which are those who "appear at the interstice of transnational sexualities and genders, modernization and globalization, and through the networks of global gay human rights discourse and Anglo-American transgender liberation" (Salah 202). Thus, a potential coalition between transgender and transCanadian methodologies could open novel ethical spaces of critical enquiry in relation to gender, violence, colonization histories, and their complex entanglements. As poet and scholar Larissa Lai reminds us, "[t]he radical work of coalition building is the building of relation, and the production of narrative, theoretical, or poetic content at the site of relation -always a struggle" (4-5). I would like to emphasize that I also understand coalition to be a shifting assemblage of potential alliances, but also frictions, which demands response-able approaches and methodologies.

The prefix "trans", with its aesthetic and ethical possibilities and ruptures, has certainly occupied a central position in my research. In the introduction to Trans-, the 2008 special issue of WSQ: Women's Studies Quarterly, guest editors Susan Stryker, Paisley Currah, and Lisa Jean Moore provide an excellent example of coalition work when they explain how their goal seeks "to take feminist scho- 
larship in expansive new directions by articulating the interrelatedness and mutual inextricability of various 'trans-' phenomena" (12). This expansive rendering of the prefix "trans"- interests me for the purposes of this essay, so I here turn to the suggestive genealogy of the prefix that Victoria Pitts-Taylor and Talia Schaffer provide in their "Editors' Note":

Trans-: Transgender, transnational, transspeciation, translation, transformation. Trans- as connection: ... transatlantic, transhistorical. Trans- as violation: transgression, transsection. Trans- ... as folded into structures of power as well as a movement of becoming. [...] trans- as a way of seeing and thinking. (9)

My own preoccupation with the politics, poetics and ethics of the Trans-, with its possibilities, its paradoxes, and its ruptures, has accompanied me for some time, finally materializing in my book, TransCanadian Feminist Fictions (2017). I here draw from material feminisms, critical race studies, non-humanist philosophy, and affect theory to propose a cross-border ethic through the lens of post $9 / 11$ feminist and queer transnational writing in Canada. In particular, I consider the corporeal, biopolitical, and affective dimensions of border crossing in the works of Dionne Brand, Emma Donoghue, Hiromi Goto, and Larissa Lai. The book sets a dialogue between the numerous ramifications of the transnational in connection to the related designation of the transCanadian, which I trace back to the work of Japanese Canadian writer, photographer, and filmmaker Roy Kiyooka, and his TransCanada Letters and Pacific Rim Letters.

Honouring this multiple heritage, CanLit scholar Smaro Kamboureli has refashioned the term through a number of groundbreaking initiatives: she founded and directed the TransCanada Institute, and she is the editor of the TransCanada Series at Wilfrid Laurier Press, which counts with 11 volumes at present, including Trans.Can.Lit: Resituating the Study of Canadian Literature (2007), co-edited with poet Roy Miki. Other scholars who have also contributed to the development of the formulation "TransCanadian" are Belén Martín-Lucas, through her 2014 work on feminist speculative fiction ("Dystopic"), and Eva Darias-Beautell, who leads the international TransCanadian Networks project. Following their work, I understand transCanadian writing as a complex assemblage of glocal, transnational, and diasporic processes that beg readers to think alongside and beyond the nation simultaneously. As a border concept, the formulation transCanadian is thus construed relationally through an inseparable mixture of coalitions, ruptures, entanglements, tensions, and alliances. In my own formulation, transCanadian writing has a deliberate feminist ethical and political stand: to interrogate power structures and hegemonic orientations ranging from neoliberal impulses, environmental crisis, patriarchal tendencies, white supremacy, and compulsory heterosexuality. This constant interrogation of borders unsettles and potentially queers Canadian literature, opening spaces for tracing alliances with trans literary production.

Thinking simultaneously through feminist, queer, and trans fictions and methodologies is also, to me, a question of response-ability; an ethical strategy to counteract the necropolitics of indifference that characterize this global age $-\mathrm{a}$ 
neoliberal age where minoritized communities are simply rendered disposable. It is with this ethical impulse in mind that I now turn to Kai Cheng Thom's work. Of Chinese ancestry, Thom is a Canadian trans woman-identified writer, performance artist, and therapist based in Toronto. As she blatantly puts it in her interview for the digital site Everyday Feminism, "we live in a disposability culture -a society based on consumption, fear, and destruction- where we're taught that the only way to respond when people hurt us is to hurt them back or get rid of them" (n.p.). The neoliberal machinery behind this politics of disposability works brilliantly: it paralyzes resistance and action, while simultaneously activating modes of oppression and exclusion. As a result, racialized and migrant transgender populations often live unsustainable lives with no access to care, something that Thom problematizes by putting risk, violence, and unpredictability at the centre of her work. Simultaneously, in poetry collections such as a place called No Homeland (2017), Thom seeks to interrogate and challenge this perverse logic by activating cross-border modes of storytelling that combine the poetic and the aesthetic, with the political and the ethical realms.

Thom's work, as illustrated in Fierce Femmes and Notorious Liars. A Dangerous Trans Girl's Confabulous Memoir, also insists on developing sustainable modes of collective response-ability, while simultaneously asking an urgent question: how can we activate empathetic and sustainable ways of living and feeling together, particularly in the case of communities with different political, ideological views? In similar ways to Audre Lorde 2 , Thom's Fierce Femmes, which was Lambda Literary Award finalist for transgender fiction in 2017, crosses the borders of memoir, biography, YA fiction, and poetry as a strategy to find new ways to tell a story, in this case, the stories of trans girls of colour ${ }^{3}$. The book opens up with an episode of failed response-ability. The narrator, a young trans girl living in the city of Gloom, connects her longing to start a new life with a day she recalls when a group of mermaids die ${ }^{4}$. Because of human degradation, the mermaids gathered at the edge of the shore dying, while humans witnessed and tried to help. The creatures, however, demanded humans to stop: "Eeerrrrrggghhhnuuugghhff [...]. Thaaaaargghhhnnnnk yeeeuuuurrrrghhhh,' she sighed. And all over the beach, the rest of the mermaids were thanking the humans who were trying to save them, and telling them enough. There was nothing we could do now to fix the mistakes we had made" (15, empha-

${ }^{2}$ Lorde's biomythography -history, myth and biography- has influenced generations of writers, including Kai Cheng Thom. As she claims in an interview for TeenVogue: "someone can pull from the roots and skeleton of their own life, but also mythologizing it in order to express greater truths" (de la Cretaz, n.p.).

${ }^{3}$ In the back cover of Thom's Fierce Femmes, the Arab-Canadian poet Trish Salah celebrates the cross-border genre of the book, which combines poetry, memoir, prose, and fairy tale. As Salah boldly contends, "The first lie is that this book is a memoir, the second is that it is not".

${ }^{4}$ Abjection and pain were usually deleted from sanitized versions of Andersen's fairy tale “The Little Mermaid" (1837). As children's literature scholar Nat Hurley claims, "from the mainstream media accounts to the medical literature and community organizations, transgender children, it would seem, are obsessed with mermaids" (258). 
sis original). As a direct consequence of humans' long-term unsustainable practices and inability to act with response-ability, the mermaids all die. Recalling feminist philosopher Rosi Braidotti's words, “Enough', or 'not going too far' expresses the necessity of framing, not the common sense morality of the mainstream cultural orthodoxy. 'Enough' designs a cartography of sustainability" (23-4), thus testing our ethical thresholds. In Thom's response-able fictions, non-normative creatures have no access to storytelling and survival as a direct result of our politics of indifference.

As I mentioned earlier, Thom aptly talks about a culture of disposability where abject populations such as trans women are systematically rendered disposable and thus dehumanized by those in power: they are rendered monstrous and nonhuman. This indifference and negligence translates into lack of access to healthcare and to a sustainable way of life. How to relate to each other in sustainable ways is at the core of Fierce Femmes and Notorious Liars. Trans girls are found dead every year in the City of Smoke and Lights, where part of the narrative takes place. Located in the heart of downtown, we find the Street of Miracles, where a community of trans femmes work, live, and try to survive. The police are depicted in the book as an instrument in the hands of those authorities that remain indifferent. They are biopolitical agents that regulate without care, as Lucrecia, one of the protagonists, explains: "What can we do? [...] The police won't do anything. We're nothing to them, remember? They couldn't care less if we live or die" (66). According to the Canadian Centre for Policy Alternatives in Manitoba, as of 2013, 71 killings of trans people had been reported in North America, two of which were reported in Canada and 69 of which were reported in the United States" (McInnes 2017). In Ontario, $20 \%$ of trans people experience physical or sexual assault due to their identity, and $34 \%$ are subjected to verbal threats or harassment. 24\% of trans Ontarians reported having been harassed by police (Bauer and Scheim 4).

Thom's fictional memoir problematizes this brutal reality by putting ethics at the centre of her fictions. During one of the riots, the narrator kills a policeman, which generates feelings of guilt and remorse. She is reminded, however, by the gang leader, that she has "a responsibility" to her "sisters" (121) to continue fighting back. What does this kind of responsibility entail? What is the role of ethics here? She needs to be accountable to the rest of the community. Paying homage to Audre Lorde's legacy, one of the femmes, Valaria, resents Lucretia, another femme, for her complicity with power structures: "You could set the master's house on fire, and instead you dance for scraps at his table" (98). However, after several episodes of violence, it is through storytelling that the femmes in the city manage to create alliances and sustain intimacy. In one of the scenes in the book that takes place in an old Cabaret, Kimaya, one of the protagonists, shares with the community the power of storytelling: "Dear femmes... I've brought us all together on this darkest of nights so we can tell our stories. We live in difficult and dangerous times, it is true. But as long as we have our stories, and we have each other, then we have hope. And this is the greatest magic of all" (139). Storytelling thus enables these women to hear each other, to feel each other, to touch each other's lives. In fact, the narrator is brought into this sense of community and is almost demanded to have her voice out. When Kimaya hands the narrator the mic, she squeezes her arm: "A pulse of 
heat radiates up from her fingers and through my shoulder into my body. It cracks the ice cubes in my blood" (141). Touching, literally and symbolically, entails an ethical encounter in that it enables response-ability, as conceptualized by Barad: it demands the reader to care, to respond, and be affected, while simultaneously stressing a sense of accountability and responsibility for the Other, in this case, the transgender subject.

In May 2014, 86 scholars, poets, and community-based writers compiled the inaugural issue of TSQ: Transgender Studies Quarterly, titled "Postposttranssexual: Key Concepts for a Twenty-First-Century Transgender Studies." This trans archive becomes an excellent navigational tool to begin to trace the range of methods and preoccupations of trans scholarship. As a feminist and transnational scholar striving to navigate CanLit's troubled waters, I am particularly interested in fleshing out the ethical possibilities of a "trans poetics," a term that "refers to diverse interpretative and compositional strategies attentive to relational movements between/across/ within linguistic, embodied, affective, and political domains" (Edwards 252). The entanglement of material, affective, and ethical forces, which lies at the heart of trans, queer, and feminist transCanadian writing, is further enmeshed in racialization processes. As Susan Stryker claims, race and racism are "broadly understood as the en meshment of hierarchizing cultural values with hierarchized biological attributes to produce distinct categories of beings who are divided into those rendered vulnerable to premature death and those nurtured to maximize their life" "Biopolitics" 40-41). In this perverse necropolitics, some transgender subjects are now slowly legally recognized, becoming "rights-bearing minority subjects within biopolitical strategies for the cultivation of life from which they previously had been excluded" ("Biopolitics" 41), whereas racialized queer and trans populations become more and more vulnerable. It is imperative, then, to counteract these oblique and direct violences by forging response-able modes of aesthetic, sociocultural, and ethical intervention, as Vivek Shraya creatively does in her work, to which I now turn.

In related ways to Kai Cheng Thom, Shraya, a Calgary-based IndoCanadian trans-identified poet and musician, crosses the borders of genre and gender in multiple ways. Her creative archive includes an impressive range of audiovisual work ${ }^{5}$, the poetry collection even this page is white, which was Lambda Literary Award finalist for transgender poetry in 2017, and incursions in queer YA and children's literature with titles such as God Loves Hair (self-published in 2011/republished by Arsenal Pulp in 2014) and The Boy and the Bindi (2016). In this essay, I will focus on Shraya's roman-à-clef novel, She of the Mountains, published in 2014 to wide critical acclaim.

The novel opens up with a creation story from Hindu mythology: "In the beginning, there is no he. There is no she. Two cells make up one cell. This is the mathematics behind creation. One plus one makes one. Life begets life. [...] We are

5 Shraya's films include, among others, I want to kill myself (2017), Holy Mother My Mother (2014), and What I LOVE about being QUEER (2012). For further information about her films and other visual work, see the author's website at https://vivekshraya.com/films/. 
never our own. This is why we are so lonely" (7). Echoing Larissa Lai's Salt Fish Girl (2002), which draws on Chinese mythology, Shraya interweaves the first-person narration of Parvati, the Hindu goddess of love, with the third-person narrative of a young IndoCanadian man struggling to make sense of his body, sexuality, and desire. Starting at school, he is subject to multiple modes of homophobic violence, which generate feelings of pain, longing, shame, alienation, and fear; unsustainable affects that block the development of his subjectivity. These microaggressions, sociologist Sonny Nordmarken contends, "scrutinize, exoticize, sexualize, or fetishize" racialized queer and trans peoples (130). Being subjugated to myriad modes of violence certainly makes the protagonist feel monstrous and abject for his difference: is he gay? Is he queer? Is he human? Shraya's narrative, in response, demands an ethics of responseability to account for these micro and macro aggressions against racialized queer and trans subjects.

In his perceptive examination of Shraya's short film and photo essay, I want to kill myself (2017), Tobias B.D. Wiggins aptly claims that "Not only have these violent legacies been enacted from the outside (through colonial histories of institutional psychiatry, for example), but we also sometimes find their lingering presence housed quite intimately and corporeally" (671). I believe this is the case with the protagonist in She of the Mountains. Significantly, it is only through the touch of another that he begins a process of desubjugation ${ }^{6}$ :

After years of hiding and being unseen, her touch was a deep thawing, a permission to feel, a memory of heat lost long ago. [...]. Next to her body, he had grown into his own body in ways he hadn't thought possible [...], revelling in its colour and even deriving pleasure from it. Next to her body, he felt a seamless, integrated connection to his own. Next to her body, he felt hope. $(55,119)$

This moment of touch in the novel allows the protagonist to work together with his vulnerability to unravel desire and pleasure as response-ability; ability to respond to the porosity of bodily and affective thresholds he is part of, while being accountable for this new knowledge in relation to her. "All touching," Barad boldly contends, "entails an infinite alterity, so that touching the Other is touching all Others, including the 'self,' and touching the 'self' entails touching the strangers within. Even the smallest bits of matter are an unfathomable multitude" ("On Touching" 214). Being in touch with another body, in this case that of a racialized woman, is ultimately an ethical entanglement that activates multiple forms of recognition and identification. As queer philosopher Judith Butler puts it in Undoing Gender, "if there are no norms of recognition by which we are recognizable, then it

${ }^{6}$ In her introduction to The Transgender Studies Reader, Stryker explains how Foucault's conceptualization of "subjugated knowledges," that is "knowledges that are below the required level of erudition or scientificity,' is precisely the kind of knowledge that transgender people [...] have of their own embodied experience, and of their relationships to the discourses and institutions that act upon and through them" (13). 
is not possible to persist in one's own being, and we are not possible beings; we have been foreclosed from possibility" (31). This moment of touch in She of the Mountains then enables the possibility for self-stylization and desubjugation; in other words, a moment of worlding.

Sandy Stone, a founder of trans studies, reads the emergence of TSQ: Transgender Studies Quarterly in 2014 not only as a coming out story, but a moment of "reading oneself aloud" (92), with its dissonances, ruptures, and pleasures. Becoming legible to oneself allows the development of self-government, which would be a necessary step for the activation of response-ability. After being in touch with the other, the protagonist in the novel begins a process of bodily and affective transformation that climaxes when he touches himself:

Why had he never thought to apply the same ardour to his own body? What would happen if he did? [...] Words and flesh were replaced by absolute feeling [...]. With no mirror or person to reflect himself back to him, he studied his body with curiosity. [...] Could it be that all this time he and his body were actually teammates, were partners? $(128,131)$

This moment of recognition in She of the Mountains entails language and corporeality to be replaced by affect. The process from misrecognition to recognition also entails a momentary transcendance from the body, which is required to fully begin to comprehend a new corporeality or transmateriality. As Barad claims, "Every level of touch [...] is itself touched by all possible others. [...] Hence selftouching is an encounter with the infinite alterity of the self. Matter is an enfolding, an involution, it cannot help touching itself, and in this self-touching it comes in contact with the infinite alterity that it is" ("Transmaterialities" 399). The protagonist in She of the Mountains eventually embraces himself and confesses: "I don't like myself when I am not with you. He finally said the words to her. And I want to" (133, emphasis original). I would argue that the deliberate ambiguity of the pronoun "her" here opens the possibility for a transgender reading of the outcome of the story.

This moment of transition and transmateriality is mirrored by Parvati's transformation into the goddess Kali at the end of the novel:

I watched this being who had erupted from my brow get on her knees, open her mouth, and drink the red river that surrounded us. With every drop of blood, she became more excited, her black skin more radiant. At one point she looked at me... and I understood that she hadn't manifested to kill. It was pleasure she sought, the sweet savour of life. (115)

Parvati's moment of becoming, in my view, indirectly helps readers visualize the narrator's bodily and affective battle, while simultaneously allowing for a moment of expression and freedom. These paralleled moments of self-creation and posthumanist rebirth, which echo Stryker's performative essay, "My Words to Victor Frankenstein above the Village of Chamounix" (1994), enable the formulation of a response-able ethics where monstrousness and difference are reclaimed. As Barad reminds us, "monstrosity, like electrical jolts, cuts both ways. It can serve to 
demonize, dehumanize, and demoralize. It can also be a source of political agency. It can empower and radicalize" ("Transmaterialities" 392). Despite myriad obstacles, Shraya's protagonist fights dehumanization and is able to form his subjectivity instead by subjugating his body to change and thus, surviving. Thom aptly argues that

Because the challenge of survival is ever-present in so many queer peoples' lives, queer communities are good at catching the now in our vision. And we have to be specific. I really mean queer people of color -particularly trans- and femmeidentified black, Latinx, and indigenous people. Many of these folks are really struggling for basic necessities. So when we do art or organizing, we have to talk in a material way about what's happening right now. (qtd. in Schwartz n.p.)

By saturating their poetry and fiction with queer and trans subjects and communities that are rendered illegible by normative ways of seeing, Thom and Shraya map response-able ethical paths in the quest for social justice. The ability to respond and be accountable, Haraway reminds us, "should not be expected to take on symmetrical shapes and textures for all the parties" (When 71). This is something crucial in Thom and Shraya's ethico-poetical experimentations given that any kind of coalition work, as I mentioned at the opening of this essay, contains fractures, tensions, and paradoxes. And yet, it is urgent that we respond by devising new forms of relationality and storytelling to counteract current dominant politics of indifference.

The Black lesbian poet and activist Audre Lorde wrote endlessly about the poetic, the socio-political, the cultural, and the ethical dimensions of difference. In her important essay "The Master's Tools Will Never Dismantle the Master's House," published in 1983, Lorde claims: "those of us who have been forged in the crucibles of difference -those of us who are poor, who are lesbians, who are Black, who are older- know that survival is not an academic skill. [...] It is learning how to take our differences and make them strengths" (99). Lorde's politics of difference crucially seek to turn racism, sexism, and indifference into response-ability as praxis for social justice. Her anti-racist politics radically clash with the current climate of indifference that prevails not only in the US, exacerbated by Donald Trump's rhetoric and practices, but also in Canada, where Indigenous claims remain largely unheard by governing powers, and Europe, where the systematically ignored plight of refugees leads to displacement and, in many cases, death. Rather paradoxically, this indifference not only leads to passivity and conformity, but also actively feeds racism, sexism, homophobia, and transphobia. In contrast, as I have attempted to tease out in this article, Kai Cheng Thom and Vivek Shraya's response-able fictions mobilize, in different ways, alternative modes of living compassionately, which, as Barad contends, "requires recognizing and facing our responsibility to the infinitude of the other, welcoming the stranger whose very existence is the possibility of touching and being touched, who gifts us with both the ability to respond and the longing for justice-to-come" ("On Touching" 219). The centrality of ethics is unquestionable here, so I will (not) close this essay with some open questions: what does it mean for minoritized populations to live and die under a dominant politics of indifference? In which ways is this indifference social, political, and economic? Is 
this indifference also a cultural matter? And if it is, and I think it is, how us feminist scholars in the contested field of CanLit can actively contribute to transforming this indifference into response-ability?

Reviews sent to author: 20 November 2018

Revised paper accepted for publication: 29 December 2018 


\section{WORKS CITED}

BARAD, Karen. "On Touching -The Inhuman That Therefore I Am." differences: A Journal of Feminist Cultural Studies 23.3 (2012): 206-223. Print.

BARAD, Karen. "Transmaterialities: Trans*/Matter/Realities and Queer Political Imaginings.” GLQ: A Journal of Lesbian and Gay Studies 2.2 (2015): 387-422. Print.

Bauer, Greta and Ayden Scheim. Transgender People in Ontario, Canada: Statistics from the Trans PULSE Project to Inform Human Rights Policy. London, ON: U. of Western Ontario, 2015. Print.

Braidotti, Rosi. “The Ethics of Becoming Imperceptible." Deleuze and Philosophy. Ed. Constantin Boundas. Edinburgh: Edinburgh UP, 2006. 133-159. Print.

Butler, Judith. Undoing Gender. New York: Routledge, 2004. Print.

Darias-Beautell, Eva. P.I. TransCanadian Networks: Excellence and Transversality from Spain about Canada towards Europe. Universidad de La Laguna, 2016-2018.

De La Cretaz, Britni. "Author Kai Cheng Thom on Writing a New Kind of Transgender Memoir." TeenVogue (April 5, 2017). 10 January 2018. Web <https://www.teenvogue.com/story/authorkai-cheng-thom-on-writing-a-new-kind-of-transgender-memoir>.

Dolphijn, Rick and Iris Van Der Tuin. "Matter feels, converses, suffers, desires, yearns and remembers': Interview with Karen Barad.” New Materialism: Interviews \& Cartographies. Eds. Rick Dolphijn and Iris Van Der Tuin. London: Open Humanities Press, 2012. 48-70. Print.

Edwards, Rebekah. “Trans-Poetics.” TSQ: Transgender Studies Quarterly 1.1-2 (May 2014): 252253. Print.

García Zarranz, Libe. TransCanadian Feminist Fictions: New Cross-Border Ethics. Montreal, QC: McGill-Queen's UP, 2017. Print.

Haraway, Donna J. When Species Meet. Minneapolis, MN: University of Minnesota Press, 2008. Print.

Haraway, Donna J. "Awash in Urine: DES and Premarin in Multispecies Response-ability." WSQ: Women's Studies Quarterly 40.1-2 (Spring/Summer 2012): 301-316. Print.

Haraway, Donna J. "Sowing Worlds: A Seed Bag for Terraforming with Earth Others." Beyond the Cyborg: Adventures with Donna Haraway. Eds. Margret Grebowicz and Helen Merrick. New York: Columbia UP, 2013. 137-146. Print.

Hurley, Nat. "The Little Transgender Mermaid: A Shape-Shifting Tale." Seriality and Texts for Young People: The Compulsion to Repeat. Eds. M. Reimer, N. Ali, D. England, and M. Dennis Unrau. New York and London: Palgrave, 2014. 258-280. Print.

Kamboureli, Smaro and Roy Miki, eds. Trans.Can.Lit: Resituating the Study of Canadian Literature. Waterloo, ON: Wilfrid Laurier UP, 2007. Print.

LaI, Larissa. Slanting I, Imagining We: Asian Canadian Literary Production in the 1980s and 1990s. Waterloo, ON: Wilfrid Laurier UP, 2014. Print.

Lorde, Audre. “The Master's Tools Will Never Dismantle the Master's House.” This Bridge Called My Back: Writings by Radical Women of Colour. Eds. Cherríe Moraga and Gloria Anzaldúa. New York: Kitchen Table Press, 1983. 94-101. Print. 
Martín-Lucas, Belén. "Dystopic Urbanites: Civilian Cyborgs in TransCanadian Speculative Fictions." Literature and the Glocal City: Reshaping the English Canadian Imaginary. Ed. Ana María Fraile-Marcos. New York and London: Routledge, 2014. 69-82. Print.

McGregor, Hannah, Julie Rak and Erin Wunker, eds. Refuse: CanLit in Ruins. Toronto: BookThug. Forthcoming 2018. Print.

McInnes, Sadie. "Violence Against Trans People in Canada: A Primer." (February 14, 2017). 20 April 2018. Web <https://policyfix.ca/2017/01/30/violence-against-trans-people-in-canada-a-primer/>.

Nordmarken, Sonny. “Microaggressions.” TSQ: Transgender Studies Quarterly 1.1-2 (May 2014): 129-134. Print.

Pitts-Taylor, Victoria and Talia Schaffer. "Editors' Note." WSQ: Women's Studies Quarterly 36.3-4 (Fall/Winter 2008): 9-10. Print.

Salah, Trish. "Subaltern.” TSQ: Transgender Studies Quarterly 1.1-2 (May 2014): 200-204. Print.

Schwartz, Claire. "Kai Cheng Thom: Giving Birth to Yourself." Guernica (29 August 2016). 12 March 2018. Web < https://www.guernicamag.com/kai-cheng-thom-giving-birth-to-yourself/>.

Shraya, Vivek. She of the Mountains. Vancouver, BC: Arsenal Pulp Press, 2014. Print.

ShraYa, Vivek. I want to kill myself. Film. (2017). 11 April 2018. Web <http://www.vivekshraya. com/films/i-want-to-kill-myself/>.

Stone, Sandy. “Guerrilla.” TSQ: Transgender Studies Quarterly 1.1-2 (May 2014): 92-96. Print.

Stryker, Susan. "My Words to Victor Frankenstein above the Village of Chamounix: Performing Transgender Rage." GLQ: A Journal of Lesbian and Gay Studies 1.3 (June 1994): 237-254. Print.

Stryker, Susan. "(De)subjugated Knowledges: An Introduction to Transgender Studies." The Transgender Studies Reader. Eds. Susan Stryker and Stephen Whittle. New York and London: Routledge, 2006. 1-17. Print.

Stryker, Susan. "Biopolitics.” TSQ: Transgender Studies Quarterly 1.1-2 (May 2014): 38-42. Print.

Stryker, Susan, Paisley Currah, and Lisa Jean Moore. "Introduction: Trans-, Trans, or Transgender?” WSQ: Women's Studies Quarterly 36.3-4 (2008): 11-22. Print.

Tном, Kai Cheng. "8 Steps Toward Building Indispensability (Instead of Disposability) Culture." Everyday Feminism (27 Nov. 2016). 10 February 2018. Web <https://everydayfeminism. com/2016/11/indispensability-vs-disposability-culture/s.

Tном, Kai Cheng. Fierce Femmes and Notorious Liars: A Dangerous Trans Girl's Confabulous Memoir. Montreal, QC: Metonymy Press, 2016. Print.

Tном, Kai Cheng. a place called No Homeland. Vancouver, BC: Arsenal Pulp Press, 2017. Print.

Wiggins, Tobias B.D. "Encountering Inheritance in Vivek Shraya's I want to kill myself." TSQ: Transgender Studies Quarterly 4.3-4 (November 2017): 668-674. Print. 
